\begin{tabular}{|c|c|c|}
\hline \multirow{2}{*}{\multicolumn{2}{|c|}{\begin{tabular}{l|l} 
DE & DE GRUYTER \\
& OPEN
\end{tabular}}} & ECONOMIC THEMES (2016) 54(2): 233-260 \\
\hline & & DOI 10.1515/ethemes-2016-0012 \\
\hline
\end{tabular}

\title{
MODELLING AND PROGNOSIS OF THE EXPORT OF THE REPUBLIC OF SERBIA BY USING SEASONAL HOLT-WINTERS AND ARIMA METHOD
}

\author{
Jelena Mladenović \\ University of Nis, Faculty of Economics, Republic of Serbia \\ $\triangle$ mladenovic.jelena88@gmail.com \\ Vinko Lepojević \\ University of Nis, Faculty of Economics, Republic of Serbia \\ $\bowtie$ vinko.lepojevic@eknfak.ni.ac.rs \\ Vesna Janković-Milić \\ University of Nis, Faculty of Economics, Republic of Serbia \\ $\square$ vesna.jankovic-milic@eknfak.ni.ac.rs
}

UDC

339.564:31

Review

paper

Received: 03.03.2016.

Accepted:

18.05.2016.

\begin{abstract}
Low labour costs as one of the key sources of export stimulation, the competitive advantage of domestic agricultural production and bilateral agreements with partner countries - all promote export as a potentially significant factor of encouragement of economic development of the Republic of Serbia.Taking into account this fact, on the one hand, and balance of payments problems that Serbia has been facing over the years, on the other hand, the subject of this paper is an analysis of trends in the Republic of Serbia export and explanation of variations in the export trends during the period from 2004 to 2014. The aim of the paper is to explore export trends forecast from January to December 2015.The analysis uses Holt-Winters and ARIMA methods for analyszing time series.The paper provides insight into the export trend forecasts for the period of 12 months, and thus confirms the possibility of practical usage of the time series analysis methods in forecasting macroeconomic variables such as export. The used methods identify increase of export during the summer and its decrease after October 2015. The paper establishes the existence of a high degree of congruence between forecasts obtained by using two methods, which confirm a high quality of the elaborated methods in the analysis of exports.
\end{abstract}

Keywords: Export, ARIMA, Holt-Winters method, Box-Jenkins methodology, foreign trade, time series

JEL classification: C32, C53, F17 


\section{Introduction}

Time series analysis and its usage have a growing importance in different research fields such as business, economics, engineering, medicine, environment, social sciences, politics and so on. This paper applies time series analysis in order to follow the trends of the Republic of Serbia export on a monthly level during the period from 2004 to 2014. Analysis of export trends during the time is important due to the profound influence of that indicator on economic growth, on the one hand, and due to problems which Serbia faces and which are connected with balance of payments, on the other hand. The subject of the paper is an analysis of the trends of the Republic of Serbia export as one of the key macroeconomic variables, as well as the explanation of variations in the export trends during the analysed period of time. The aim of the paper is to explore the export trends forecast during 2015, as well as giving comparative analysis of the results of export extrapolation gained by using Holt-Winters and ARIMA methods.

The Statistical Office of the Republic of Serbia is used as a data source. Holt-Winters smoothing and ARIMA method are used as time series methods for variables' trends forecast during the time. Microsoft Excel and EViews 7 have been used during the research. Forecasting refers to the period JanuaryDecember 2015.

The first part of the paper shows an overview of the literature about export trends and its importance for a national economy. The second part is occupied with analysis of Serbian overall foreign trade picture with the emphasis on the export. This part of the paper shows trends of foreign trade deficit, export, import content of exports, foreign trade balance by type of activity, as well as the most important foreign trade partners of the Republic of Serbia in 2014. The third part presents the research methodology used in the paper, where the authors explain Holt Winters smoothing and ARIMA method, emphasizing the Box-Jenkins methodology. Finally, the fourth part contains the results of the conducted research.

\section{Overview of the Literature about the Role and Importance of the Export for a National Economy}

Numerous theories about foreign trade demonstrate a great importance and continual actuality of that issue. Generally, all authors who have been occupied with the role and importance of the foreign trade could be classified as liberals and protectionists, with a separation of the mercantilism as a precursor theory. The mercantilism which is caused by socio-economic conditions in Europe from the beginning of XV to the middle of XVIII century, observed the wealth of a nation through its quantity of the silver and gold. Thus, foreign trade was 
considered as a source of wealth, because mercantilists saw a foreign trade surplus as the only factor of increasing gold supply in a country, and hence a wealth of nation. On the other hand, internal trade results only in the change of silver and gold owner, but not in the change of gold supply in a country. Liberal theory of the foreign trade looks on a country specialization for production of certain products as not only necessary, but also highly worth for every country. As for the protectionism, it propagates the protection of an insufficiently developed country for a certain time, with the aim of its strengthening and forming as an equal participant in the world market (Todorović \& Marković, 2013, p. 52, 55).

The role of foreign trade in keeping and encouraging economic development has been the subject of different points of view. From the orthodox point of view, import should be a supported activity, because the competitive pressure of international trade stimulates growth through the strengthening of efficient resource allocation, as well as through the involvement of innovation and learning from a foreign competition. On the other hand, export means the widening of aggregate demand, the advancement of the full employment of factors of production and the increase of income which can be used for the payment of import as the encouragement of consumption and technological progress. The orthodox point of view can be presented by Nurkse'ssentence that foreign trade is "engine of growth" which drives the global economy of XIX century (Nurkse, 1960, from Moon, 1998, p. 8).

On the other hand, some economists emphasise the importance of external markets for foreign trade, especially the role of Third World countries. The export of these countries traditionally has the source in sectors whose demand is not perspective, and which has limited intersectoral relations. These sectors produce primary products and they are characterised by a low wage level. Additionally, the great expansion of existing branches is not only impossible, but also undesirable. Meanwhile, the large number of importing products from powerful foreign economic branches can uncapacitate the development of new domestic branches. In that way, trade dependence can lead to distortions which endanger economic growth. What is more, an extensive reliance on trade can cause the great country's sensitivity to market distortions or political pressures, especially if that trade is concentrated on the small number of products or the small number of trade partners - what is typical for small and poor countries (Moon, 1998, p. 9).

Between these two opposed attitudes there is a middle ground, whose representative is Kravis. He considers trade as the consequence, but also as the cause of growth in the same time. Furthermore, he thinks that trade is just one of the various causes of economic growth. Aside, trade stimulates economic growth just under certain conditions, and what is the most important, the main drivers of growth are internal (Kravis, 1970, p. 859). Levis addes that "the 
engine of growth should be technological change, with international trade serving as a lubricating oil and not as fuel”(Lewis, 1978, from Moon, 1998, p. 9).

The existence of cheap labour force in developing countries can enable competitive advantage for the production and export of labor-intensive sectors. The development of export-oriented and labor-intensive sectors can create an enormous income and the possibilities of employment for poor inhabitants, but it also can enable the absorption of advanced skills to developed countries through export. However, not all developing countries with cheap labor force are equally successful in the export of labor-intensive products. It results in a great difference between various developing countries' realized performances. According to some authors, factors which determined this success are the transport infrastructure of the exporting country and transport costs (Mottaleb \& Kalirajan, 2014, p. 1450043-3).

Different schools of economic thought have various attitudes about the influence of the export on economic growth. Two opposed attitudes can be found in the papers of neoclassicists and Marxists. The argument of the neoclassical theory of foreign trade about the contribution of export and trade to economic performances is based on the better allocation of resources. Marxists and neo-marxists considered foreign trade as the mechanism of exploitation of less developed countries by the industrialised world (Rati, 1985, p. 425).

Some authors looked at the importance of export and foreign trade for economic growth through technical and technological infrastructure. Country openness for international trade and global market give the possibility for the adoption of the most advanced production technology and management techniques, what stimulates added investment in research and development as well as the engagement of the most qualitative human resources. In that way the conditions for efficiency increase in costs and production volume are provided, what will finally lead to the increase in production level (Milenković, 2012, p. 140).

Export directly contributes to export sector growth in different ways. Export increases the usage of existing capacities, stimulating the growth of investment. Furthermore, export makes possible for enterprises to take advantage of the economy of scales through the increase in production. Exit to the world market raises the awareness of technological progress and gives incentives for the increase in innovations. Export is a complex phenomenon, so it is important to analyse the relation between these macroeconomic variables through the mechanisms of interaction, as well as their synergistic effect on a country's export (Marković \& Marković, 2014). Eventually, exporters are faced with foreign competition pressure which stimulates efforts for efficiency increase. Thus, if the output of every two economic sectors is determined by typical 
neoclassical production function, it is expected greater marginal factor productivity in export sectors in comparison to non-export-oriented sectors (Ibrahim \& MacPhee, 2003, p. 258).

Hussain and Saaed carried out the research on the connection between import, export and economic growth by using ARIMA method. These authors conclude that import causes a great increase of export and economic growth. They explained that conclusion in the following way - the import of capital goods used for the development of the infrastructure contributes to the exports of that infrastructure products, what has growth increase as a synergistic effect (Hussain \& Saaed, 2015, p. 68). According to that, the structure of import is the factor of a great importance, so the import increase is not per se a negative phenomenon.

The influence of import on economic development can be analysed through instrument known as a foreign trade multiplier. It is the connection between the national income and export of the economy. The foreign trade multiplier may be defined as an amount by which national income will be raised by unit increases in exports (Acin et al., 2006, p. 43). This indicator means that the export increase for one unit leads to the income increase, which causes import and saving increase in the proportion conditioned by the national standard of living level.

There is a possibility that the increase of export and domestic consumption leads to the increase of domestic investment through an acceleration process. Namely, domestic production capacities are increased through added investment in order to satisfy the increased demand of exporters and domestic consumers. It is uncertain to what extent will operate multiplier's effect. The effect will probably be small or absent if economy operates below the level of full employment of production factors (Hultman, 1967, p. 149).

\section{The Analysis of Export and the Foreign Trade Picture of the Republic of Serbia}

The main feature of the foreign trade position of the Republic of Serbia is the existence of the foreign trade deficit during a long period. The main problem is the structure of deficit, hence Serbia imports the great amount of products which it produces itself. Actual data show reduced deficit, although it has the value of 5.763 million dollars in 2014. The following graph represents deficit trends in the period from 2004 to 2014. 
Graph 1 Foreign trade deficit, Republic of Serbia, 2004-2014, million dollars

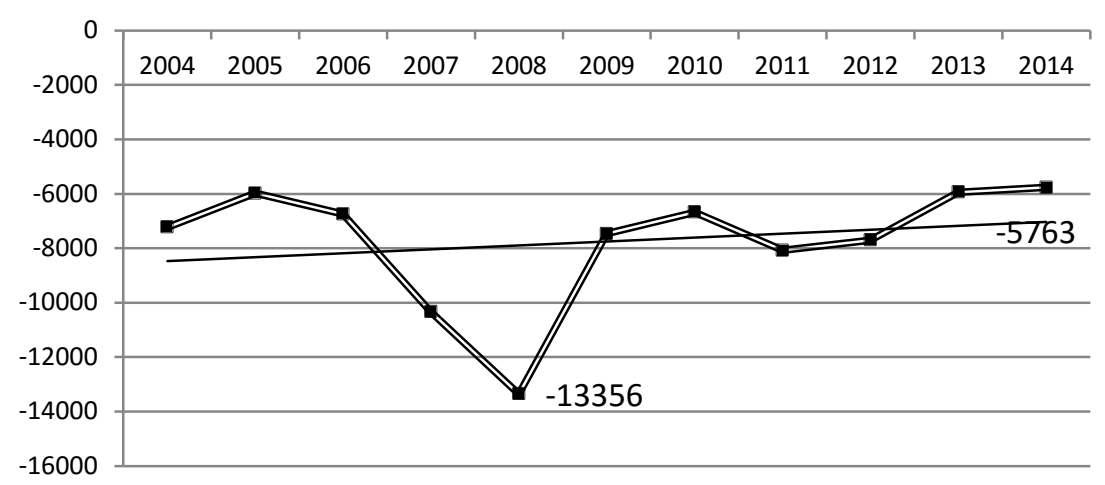

Source: Authors, based on Statistical Office of the Republic of Serbia data

Graph 1 shows that the foreign trade deficit was the highest in 2008 when it recorded the value of 13.356 million dollars. On the other hand, the lowest deficit was achieved in the last year, 2014, when a negative difference between export and import amounted 5.763 million dollars. The trendline has a slight positive growth, what is the proof of gradual decrease of deficit during several last years.

\section{Graph 2 Export value in million dollars, 2004-2014, Republic of Serbia}

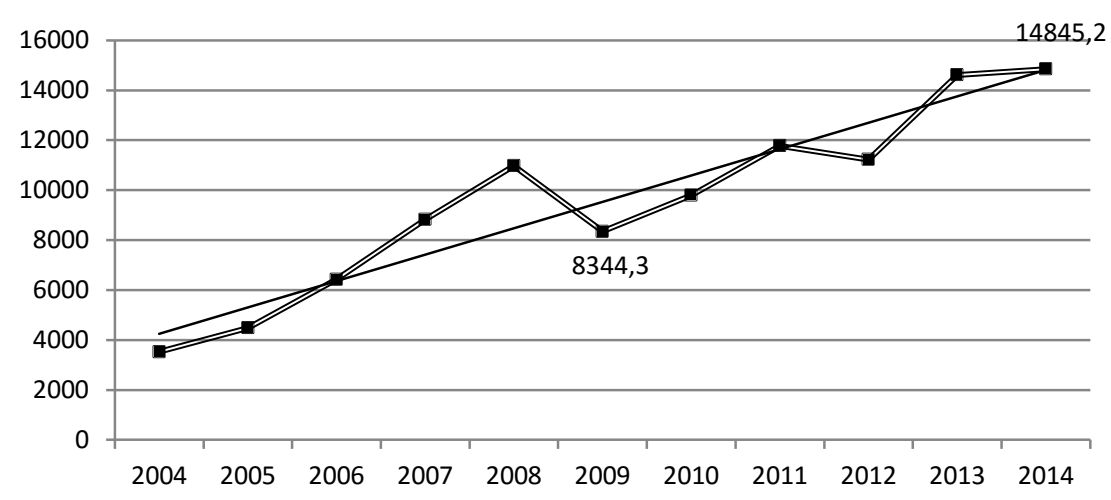

Source: Authors, based on Statistical Office of the Republic of Serbia data

As for the export trends, it records growth trend from 2004 to 2014. Except for 2009 and 2012 when export fell, we can see the growth of this indicator during the whole analysed period. It recorded value of 14.845,2 million dollars in 2014. 


\section{Graph 3 Import contents of export (\%), Republic of Serbia}

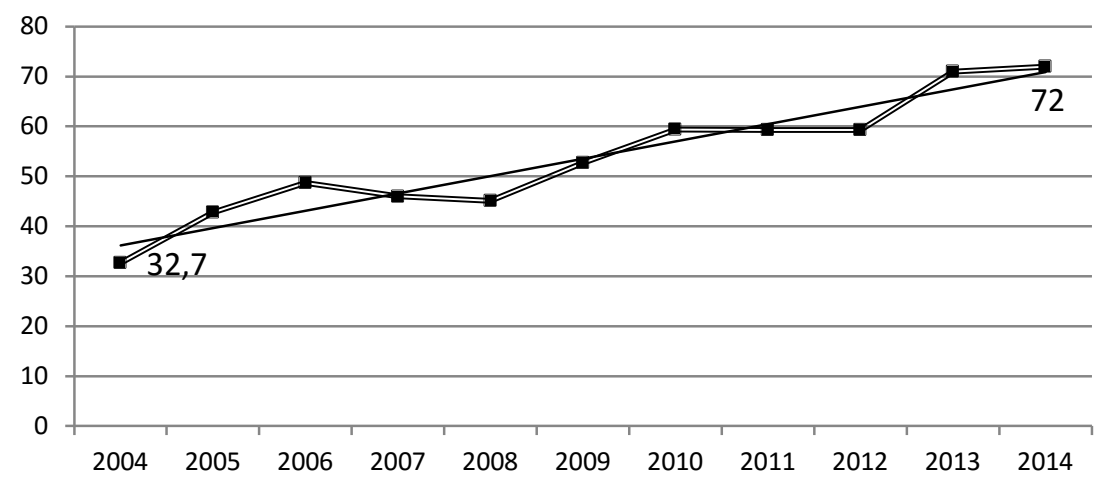

Source: Authors, based on Statistical Office of the Republic of Serbia data

The previous graph gives us similar conclusion to others, so far derived conclusions. From 2004 import contents of export has been increasing, hence trendline has a greater positive slope in comparison to the foreign trade deficit trendline. Import contents of export were $32.7 \%$ in 2004, while a positive change was made in 2014 when this indicator amounted to $72 \%$.

Graph 4 The ten most important foreign trade partners of the Republic of Serbia in 2014, in thousands of dinars

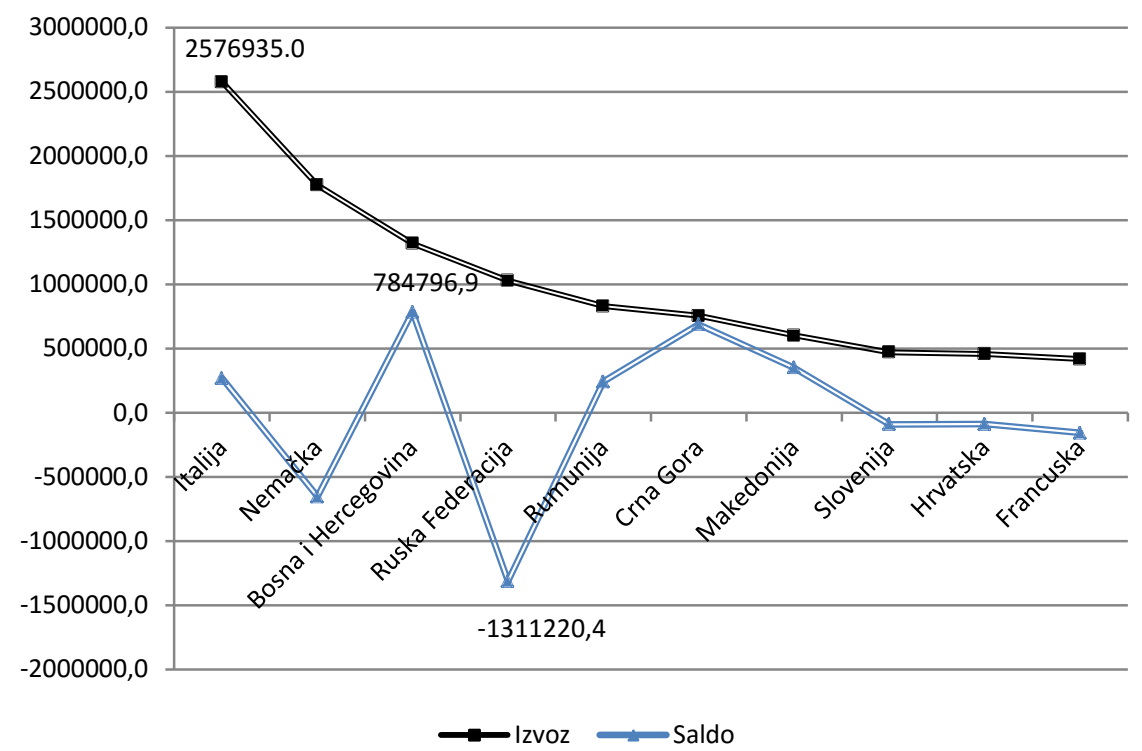

Source: Authors, based on Statistical Office of the Republic of Serbia data 
The previous graph represents the ten most important foreign trade partners of the Republic of Serbia in 2014.The greatest export value was realized in the trade exchange with Italy, amounting to 2.576 .935 thousand dollars. As for the largest positive trade balance, Bosnia and Hercegovina stands out among observed ten countries. Serbia realised the surplus in the foreign trade exchange with Bosnia and Hercegovina in the value of 784.796,9 thousand dollars. The foreign trade surplus was achieved also in trade with Italy, Romania, Montenegro and FYR Macedonia. It is interesting that Serbia accomplished foreign trade deficit in the trade exchange with the Russian Federation. Even though the import of oil and gas from Russia makes the largest part of import value from Russia, there is a conclusion about an unjustifiably high deficit in the trade exchange with this country.Naimly, the existence of The Free Trade Agreement from 2000 gives domestic exporters the possibilities of achieving the advantages of tax-free export in Russia for the majority of products. Thus, one of the imperative of export strategy is the increase of domestic product export in Russia as well as the reduction of the existing foreign trade deficit.

\section{Graph 5 Value of foreign trade balance according to classification of activities,} 2014, Republic of Serbia, million dollars

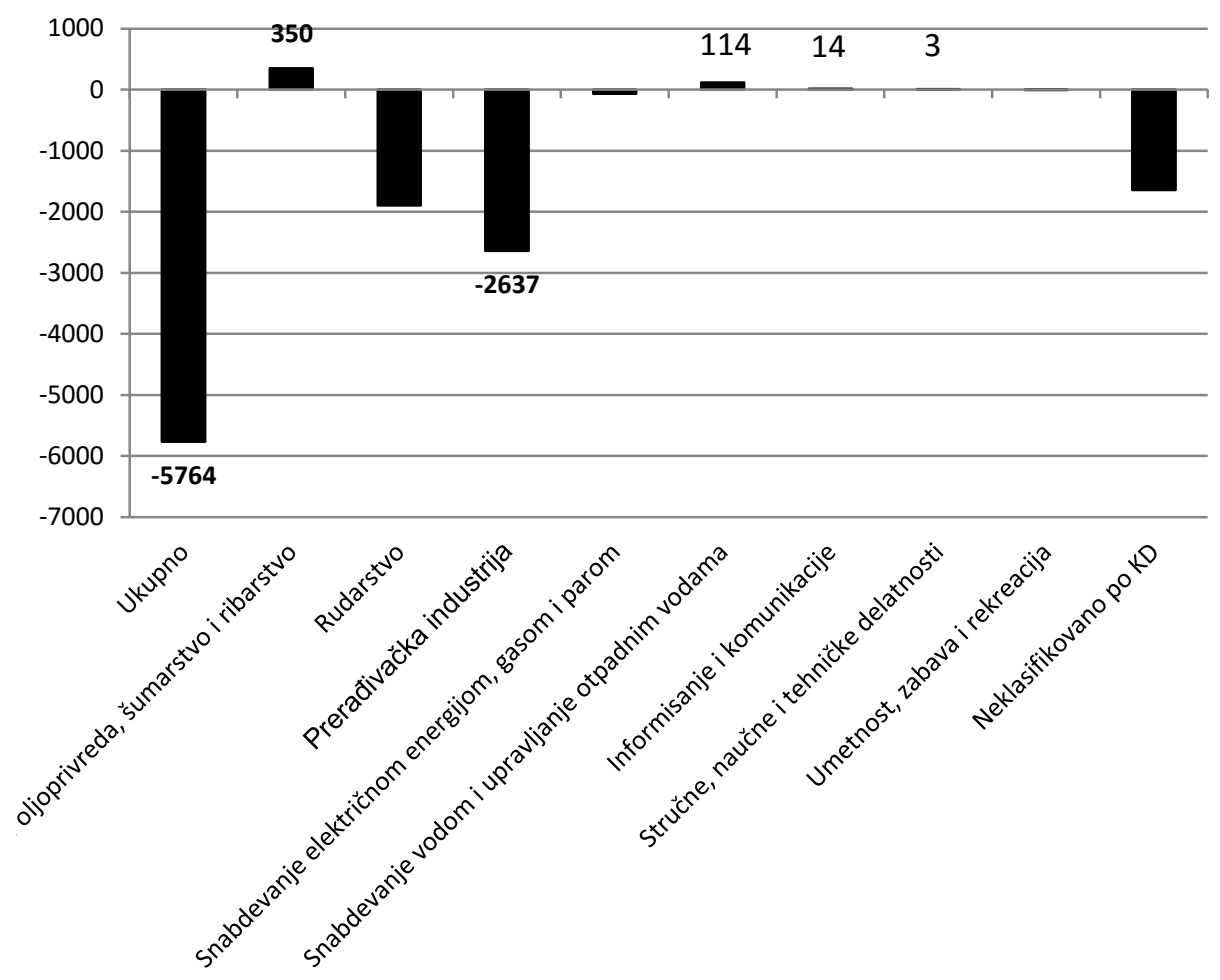

Source: Authors, based on Statistical Office of the Republic of Serbia data 
Graph 5 shows the positive share of the agriculture, forestry and fishing (350 million dollars), the water supplying and wastewater management (114 million dollars), the information and communication(14 million dollars), as well as the professional, scientific and technological activities (3 million dollars) in the structure of foreign trade balance according to the classification of activities. All remaining activities record the negative value of foreign trade balance, where the biggest negative share in that balance has a processing industry (2.637 million dollars). This results in total negative foreign trade balance in 2014, i.e. in the foreign trade deficit value of 5.764 million dollars.

Accordingly, it can be concluded that the existence of positive trend in export and foreign trade balance, with the presence of numerous problems as well as a large space for the improvement of foreign trade picture of Serbia. One of the key competitive advantages of the Republic of Serbia is low labor force price. This advantage should be used for the encouragement of export through production by lower prices. Furthermore, taking into account the fact about the competitive advantage of domestic agriculture, as well as the existence of numerous bilateral agreement with partner countries, we deduce that export is an important potential factor of encouragement of economic growth of the Republic of Serbia.

\section{Research Methodology}

Time series analysis has as an aim identification of models that explains variations in the conduct of some phenomenon during a time and its future state forecast on the basis of noted condition in the past and present. There are numerous methods to be used in time series analysis. This paper uses two methods: Holt-Winters smoothing and ARIMA method, with the aim of forecasting monthly export trends in the Republic of Serbia for the period January-December 2015.

Seasonal Holt-Winters smoothing is used for data with trends and seasonal character. The theory recognizes linear, exponential and damped trend. Linear trend means that time series increases (decreases) in an equal absolute amount from one period to another. The exponential trend implies that time series increases (decreases) in an equal relative amount from one period to another. A damped trend means a combination of linear and exponential trend, where an increase (a decrease) is existed in absolute amount in the first period, while the phenomenon experiences relative changes in every following period by the principle of exponential trend. Seasonality is defined as a tendency of timeseries data to exhibit behavior that repeats itself every $\mathrm{S}$ period. The term season is used to represent the period of time before behaviour begins to repeat itself ( $\mathrm{S}$ - season length in periods). 
There are two main Holt-Winters models - Multiplicative and Additive. The additive model implies kind of forecast where an expected seasonal amount of certain phenomenon increase is added to the annual average. The multiplicative model includes a relative change of analysed variable which is greater if the absolute amount of this variable is greater, and inverse. In additive models, series shows stable seasonal fluctuations, notwithstanding a general level of time series trends. As for a multiplicative model, seasonal fluctuation amount varies depending on general series level.

The additive seasonal model is used when time series data show additive seasonality. This model is appropriate for those time series that have amplitude of the seasonal pattern independent of the average level of the series. The additive version of the model can be described by the following formulas (Valakevicius \& Brazenas, 2015, p. 385):

$$
\begin{gathered}
L_{j}=\alpha\left(y_{j}-S_{j-s}\right)+(1-\alpha)\left(L_{j-1}+b_{j-1}\right) \\
b_{j}=\beta\left(L_{j}-L_{j-1}\right)+(1-\beta) b_{j-1} \\
S_{j}=\gamma\left(y_{j}-L_{j}\right)+(1-\gamma) S_{j-s} \\
F_{j+1}=L_{j}+b_{j}+S_{j+1-s} \\
j=s+1, s+2, \ldots,
\end{gathered}
$$

where $\alpha, \beta$ i $\gamma \in[0,1]$ are the smoothing parameters, $L_{j}$ is the smoothed level at time $j, b_{j}$ is the change in the trend at moment $j, S_{j}$ is the seasonal smooth at moment $j, s$ is the number of periods in the season, and $F_{j+1}$ is one step ahead forecasted value. This initial values are calculated by the following formulas:

$$
\begin{gathered}
L_{s}=\frac{1}{S} \\
b_{s}=\frac{1}{s}\left[\frac{y_{s+1}-y_{1}}{s}+\frac{y_{s+2}-y_{2}}{s}+\cdots+\frac{y_{s+s}-y_{s}}{s}\right. \\
S_{j}=y_{j}-L_{s}, \\
j=1,2, \ldots, s .
\end{gathered}
$$

Although the additive seasonal Holt-Winters model is a broadly used for forecasting in time series analysis, some authors consider its basic form as an insufficiently effective for giving reliable estimates of time series. Analysing the results of the additive seasonal Holt-Winters model, Lawton (1998, p. 394) noticed its good forecast results. However, when it comes to errors in the estimates of the time series features, this author marked trend as correctly 
estimated, but not the values for the level and the seasonal terms. Some strategies for adjusting and correcting Holt-Winters estimates are annual renormalisation, annual component adjustment and the variant of adjusted HoltWinters suggested by Robert and McKenzie.

Multiplicative seasonal model is used when data have multiplicative seasonality. The Multiplicative model is a more frequently implemented in computer forecasting software in comparison to additive seasonal model. Although the multiplicative Holt-Winters method provides us with a forecast for each future time period, it has a disadvantage related to the forecast error. Namely, this method does not give us information about forecast error. In order to solve that problem, literature suggests prediction interval which can have form presented in the following formula (Koehler et al., 2001, p. 269):

$$
\text { Forecast } \pm k x \sqrt{\text { variance of the forecast error, }}
$$

where element $k$ depends on the probability distribution of the forecast error.

Multiplicative seasonal model can be described by the following formulas (Valakevicius \& Brazenas, 2015, p. 386):

$$
\begin{gathered}
L_{j}=\alpha\left(\frac{y_{j}}{S_{j-s}}\right)+(1-\alpha)\left(L_{j-1}+b_{j-1}\right) \\
b_{j}=\beta\left(L_{j}-L_{j-1}\right)+(1-\beta) b_{j-1} \\
S_{j}=\gamma \frac{y_{j}}{L_{j}}+(1-\gamma) S_{j-s} \\
F_{j+1}=\left(L_{j}+b_{j}\right) S_{j+1-s} \\
j=s+1, s+2, \ldots
\end{gathered}
$$

The initial values of the model are computed using the same formulas as in the additive version of the model, except for seasonal variables:

$$
S_{j}=\frac{y_{j}}{L_{s}}, \mathrm{j}=1,2, \ldots, \mathrm{s}
$$

Due to the complexity of the basic versions of the two mentioned models of Holt-Winters method, there are mostly used their simplified versions. The simplified versions do not include variable $b$.

ARIMA time series methods (Autoregressive Integrated Moving Average) are based on the three-stage Box-Jenkins methodology. Pioneers in that area are Box and Jenkins, who popularized approach that combines autoregressive models and moving average models. Although both models were used even earlier, the contribution of Box and Jenkins consists in the development of the 
systematic methodology for the identification and estimation of models which can include both approaches. That fact qualifies Box-Jenkins models in a high class methodology (Dobre \& Alexandru, 2008, p. 156).

The Box-Jenkins methodology is a powerful method for determining mathematical models of various stochastic-process phenomena. Essentially, this is the methodology of systematic multi-stage modelling for identifying and estimating models which include and combine autoregressive (AR) and moving average (MA) models, in order to find the best adjusted time series of original data, and make forecasts. The basic advantage of Box-Jenkins methodology is extracting a large number of information from analysed empirical time series, using a small number of parameters. Furthermore, this methodology can be used for modelling both stationary and non-stationary time series, with and without seasonal patterns (Baldigara \& Mamula, 2015, p. 21).

The disadvantage of using the Box-Jenkins methodology is related to the period of the forecast. Namely, the period of twelve months, which is used as a forecast period in our paper can be evaluated as a relatively short. Although analysis, technically, can be conducted for a longer forecast period, the accuracy of forecasting will be smaller in that case. Choosing forecast period of twelve months, we chose accuracy instead of forecast period length.

Seasonal character of time series is a common and frequent pattern of changes that repeats over $\mathrm{S}$ time period. If observed phenomenon is seasonal, it is necessary to generalize ARIMA process and create the SARIMA model in order to relieve seasonality. Seasonal Autoregressive Integrated Moving Average (SARIMA) process is designed to model time series with trends, seasonal pattern and short time correlation. It is developed from the standard model of Box and Jenkins (1970) and incorporates both seasonal autoregressive and moving average factors into the modelling process. The seasonal ARIMA (SARIMA) models incorporate both non-seasonal and seasonal factors in a multiplicative model as follows (Etuk, 2012, p. 29):

$$
\operatorname{ARIMA}(p, d, q) \times(P, D, Q)_{s}
$$

where:

$$
\begin{aligned}
& p \text { - non-seasonal AR order, } \\
& d \text { - non-seasonal differencing, } \\
& q \text { - non-seasonal MA order, } \\
& P \text { - seasonal AR order, } \\
& Q \text { - seasonal MA order, } \\
& S \text { - time span of repeating seasonal pattern. }
\end{aligned}
$$


The Box-Jenkins methodology includes three interactive steps: (1) the model identification stage, (2) the estimation stage, (3) the diagnostic checking stage (Baldigara \& Mamula, 2015, p. 22). The first stage implies verification of time series stationarity. The estimation stage involves model defining, so it is the most important step of used methodology. Following scheme shows theoretical base for defining adequate model.

Table 1 Types of autocorrelation functions

\begin{tabular}{|ll|}
\hline Shape of time series trends & Proposed model \\
\hline Exponential, descending to zero & $\begin{array}{l}\text { AR model, the use the plot of partial } \\
\text { autocorrelation for determining AR } \\
\text { variables. }\end{array}$ \\
\hline $\begin{array}{l}\text { Time series with a changing sign, that } \\
\text { converges to zero }\end{array}$ & $\begin{array}{l}\text { AR model, the use the plot of partial } \\
\text { autocorrelation for determining AR } \\
\text { variables. }\end{array}$ \\
\hline $\begin{array}{l}\text { Time series has several spikes, the others } \\
\text { stay at zero level. }\end{array}$ & $\begin{array}{l}\text { Moving average model (MA) } \\
\text { Time series declines after several lags. }\end{array}$ \\
\hline High values at fixed intervals. & $\begin{array}{l}\text { Combination of autoregressive model } \\
\text { and moving average model (ARMA) }\end{array}$ \\
\hline
\end{tabular}

Source: Nastić, N. (2012). Empirijsko istraživanje cijena u BiH 2006-2010. i prognoza inflacije za 2011. godinu - primjena ARIMA modela, Zbornik radova Ekonomskog fakulteta, 6, p. 91-104.

Within the diagnostic checking stage it we must establish validity of the model by checking key parameters. Realization of all three stages of BoxJenkins methodology results in trend prognosis of indicator which is the object of analysis in defined time period.

\section{Research Results}

\subsection{Holt-Winters Smoothing}

Using the seasonal Holt-Winters smoothing, the authors tried to overcome the problem of the same forecasted values for every forecast period, what is the key disadvantage of exponential smoothing. When it comes to use of Holt-Winters method, we started from establishing two models - additive and multiplicative. Both models used following parameters: 0.7 for alfa $(\alpha), 0.5$ for beta $(\beta)$ i 0.2 for gama $(\gamma)$. That choice of constants is caused by intense for giving greater 
importance new values in exponential smoothed components and giving equal importance new and earlier trend assessment.

After defining smoothing parameters, the next step was establishing additive and multiplicative model of export trends for the period January 2004 December 2014. In order to choose a high quality model, we calculated an error deviation for every model. Root mean square error (RMSE) and Residual sum of squares (RSS) are used as indicators of error deviation. Root mean square error for the additive model amounts 73.11527, while the same indicator for the multiplicative model has the value of 69.01904. The residual sum of squares as the error deviation between the regression function and database records 705651.2 for additive model, and 628798.9 for multiplicative model. These data are shown in the following table.

Table 2 Measurement of accuracy for forecasts given by Holt-Winters method

\begin{tabular}{|ccc|}
\hline $\begin{array}{c}\text { Model/ Accuracy measures } \\
\text { forecast }\end{array}$ & $\begin{array}{c}\text { Root mean square error } \\
\text { (RMSE) }\end{array}$ & $\begin{array}{c}\text { Residual sum of squares } \\
\text { (RSS) }\end{array}$ \\
\hline $\begin{array}{c}\text { Additive model } \\
(\boldsymbol{\alpha}=\mathbf{0 . 7} \boldsymbol{\beta}=\mathbf{0 . 5}, \boldsymbol{\gamma}=\mathbf{0 . 2})\end{array}$ & 73.11527 & 705651.2 \\
\hline $\begin{array}{c}\text { Multiplicative model } \\
(\boldsymbol{\alpha}=\mathbf{0 . 7} \boldsymbol{\beta}=\mathbf{0 . 5}, \boldsymbol{\gamma}=\mathbf{0 . 2})\end{array}$ & 69.01904 & 628798.9 \\
\hline
\end{tabular}

Source: Authors, based on Statistical Office of the Republic of Serbia and EViews 7 data

Observing calculated values of model accuracy, we can conclude smaller values in multiplicative model, for both RMSE and RSS. It means that root mean square error and the residual sum of squares smoothed from empirical data are smaller in the multiplicative model in comparison to the additive model. Eventually, this leads to the conclusion about greater acceptability of multiplicative model, as well as about better forecast given by this model. Thus, the multiplicative model will be used in the further analysis.

With the aim of clearer analyzing given results, there is shown initial time series of export trends in the period January 2004 - December 2014, as well as smoothed values given by the Holt-Winters method. Forecasted export values are clearly shown in the graph. According to the given model, it is expected that the export's continuous decrease started at the end of 2014, also in January and February 2015, while increasing trends are expected starting from March 2015. After that, from March to October 2015 it is noticed a stagnation trend, while new declining series of the analysed indicator starts from November and December 2015. The biggest forecasted export value refers to July, while the lowest one was marked in January 2015. 
Table 3 Export trends forecast using the multiplicative Holt-Winters smoothing method

\begin{tabular}{|c|c|}
\hline Forecast period & Export forecast (in million dollars) \\
\hline January 2015 & $\mathbf{8 8 2 . 0 8}$ \\
\hline February 2015 & 980.26 \\
\hline March 2015 & $1.200,11$ \\
\hline April 2015 & $1.140,25$ \\
\hline May 2015 & $1.141,94$ \\
\hline Jun 2015 & $1.210,31$ \\
\hline July 2015 & $\mathbf{1 . 2 1 9 , 1 3}$ \\
\hline Avgust 2015 & $1.111,04$ \\
\hline September 2015 & $1.202,74$ \\
\hline Oktober 2015 & $1.207,67$ \\
\hline November 2015 & $1.168,56$ \\
\hline December 2015 & $1.148,51$ \\
\hline
\end{tabular}

Source: Authors, based on Statistical Office of the Republic of Serbia data

Graph 6: Initial, smoothed and forecasted export values

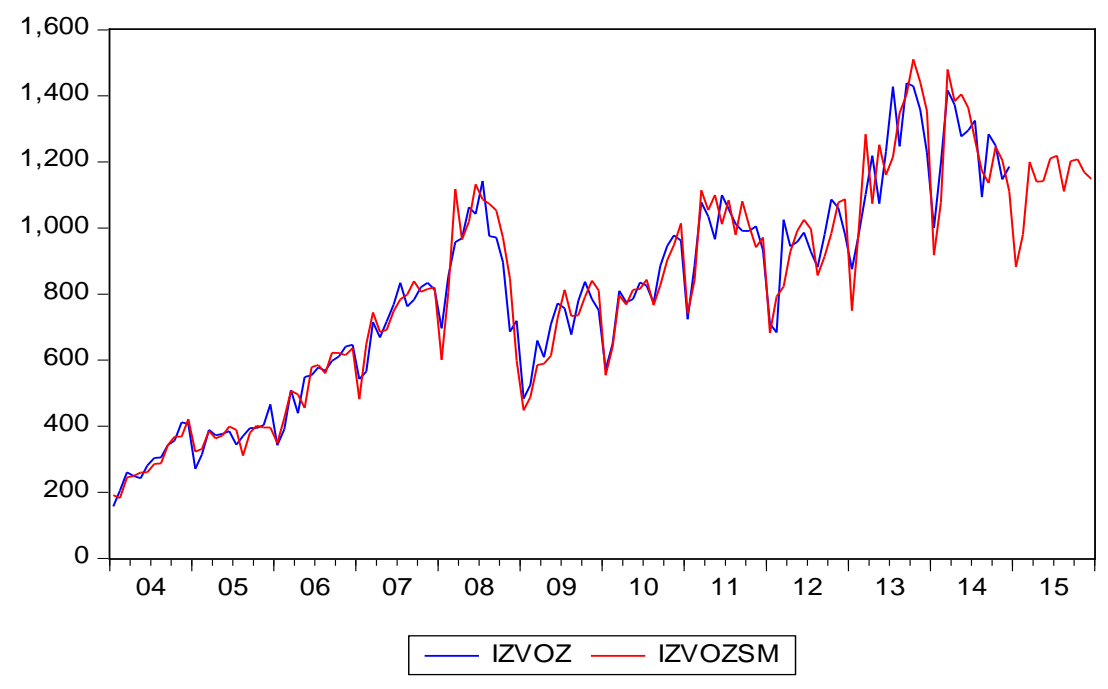

Source: Authors, based on Statistical Office of the Republic of Serbia data and EViews 7 data 


\subsection{ARIMA Method}

Within the application of ARIMA method, there are conducted all three mentioned phases of the Box-Jenkins methodology. During the first phase - the model identification, it is monitored the time series stationarity, whereas the basic precondition for the creation of ARIMA model is a stationary time series, i.e. observed time series must have a constant variance and mean at a time. The key assumption within a time series analysis is the stationarity and linearity of every dynamic process, i.e. stochastic process which generates a phenomenon at a time. On the basis of graphical representation, correlogram and unit root tests, (Augmented Dickey-Fuller Unit Root Test i Phillips-Perron Unit Root Test), there is confirmed the stationarity of time series.

Graph 7 Export trends, January 2004-December 2014, Republic of Serbia, mil. dollars

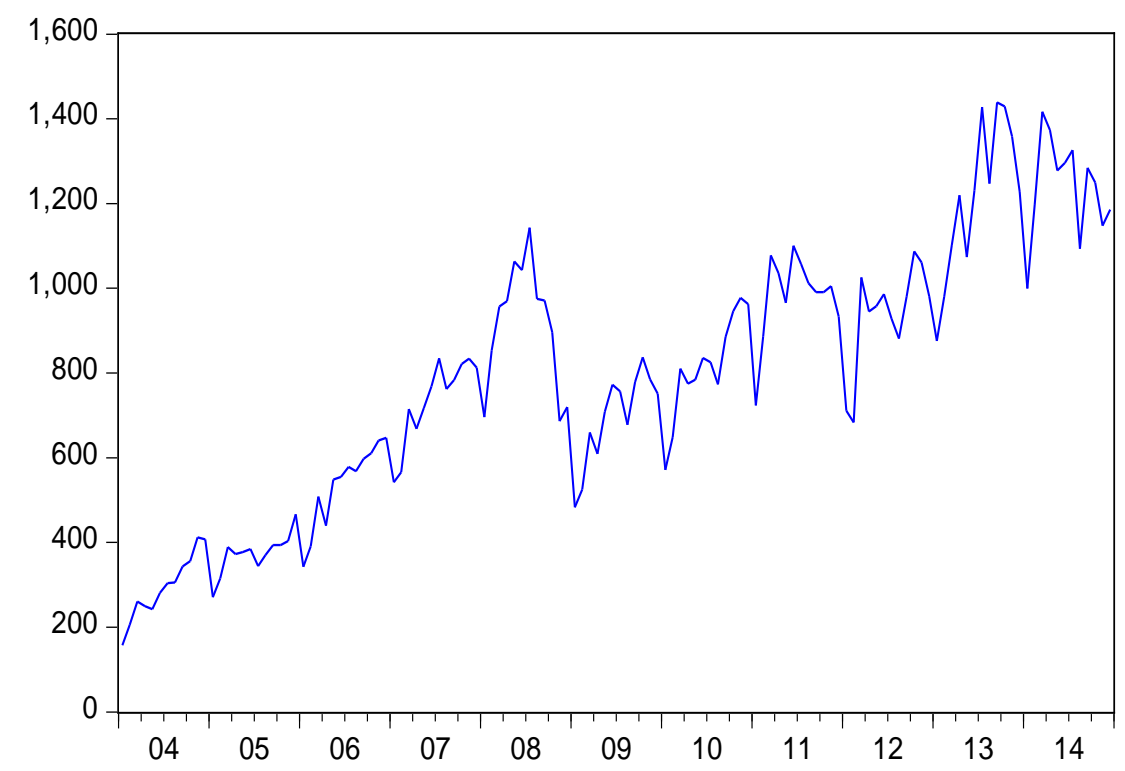

Source: Authors, based on Statistical Office of the Republic of Serbia data and EViews 7 data

The Graph above shows the existence of marked trend in the movement of export during the 11 year period. Thus, it is noted a non-stationarity as a characteristic of the analysed time series. The confirmation of that conclusion was conducted through the following time series correlogram. 
Mladenović, Lepojević,Janković-Milić/ Economic themes, 54 (2):233-260 249

\section{Graph 8 Correlogram of Export}

\begin{tabular}{|c|c|c|c|c|c|c|c|c|}
\hline \multicolumn{2}{|c|}{ Autocorrelation } & \multicolumn{3}{|c|}{ Partial Correlation } & \multirow{2}{*}{$\frac{A C}{0.927}$} & \multirow{2}{*}{$\frac{\text { PAC }}{0.927}$} & \multirow{2}{*}{$\frac{\text { Q-Stat }}{116.08}$} & \multirow{2}{*}{$\begin{array}{l}\text { Prob } \\
0.000\end{array}$} \\
\hline 1 & & I & & 1 & & & & \\
\hline 1 & & 1 & ا & 2 & 0.871 & 0.081 & 219.33 & 0.000 \\
\hline 1 & & 1 & $\sqsupseteq$ & 3 & 0.842 & 0.177 & 316.54 & 0.000 \\
\hline 1 & & 10 & 1 & 4 & 0.800 & -0.063 & 405.03 & 0.000 \\
\hline 1 & & 1 & اין & 5 & 0.770 & 0.083 & 487.57 & 0.000 \\
\hline I & & 10 & 1 & 6 & 0.729 & -0.096 & 562.27 & 0.000 \\
\hline 1 & & 1 & i & 7 & 0.698 & 0.065 & 631.12 & 0.000 \\
\hline 1 & $\square$ & 10 & 1 & 8 & 0.663 & -0.070 & 693.78 & 0.000 \\
\hline 1 & & 1 & 1 & 9 & 0.632 & 0.057 & 751.31 & 0.000 \\
\hline 1 & $\square$ & 10 & 1 & 10 & 0.599 & -0.076 & 803.28 & 0.000 \\
\hline 1 & 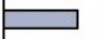 & 1 & $\square$ & 11 & 0.596 & 0.264 & 855.28 & 0.000 \\
\hline 1 & 品 & 1 & ים & 12 & 0.606 & 0.085 & 909.40 & 0.000 \\
\hline 1 & 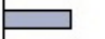 & + & 1 & 13 & 0.543 & -0.419 & 953.29 & 0.000 \\
\hline 1 & $\square$ & 吅 & 1 & 14 & 0.484 & -0.136 & 988.47 & 0.000 \\
\hline 1 & $\square$ & 1 & יاط & 15 & 0.459 & 0.129 & 1020.3 & 0.000 \\
\hline 1 & $\square$ & 1 & 1 & 16 & 0.423 & -0.017 & 1047.5 & 0.000 \\
\hline 1 & $\square$ & I & 1 & 17 & 0.392 & 0.004 & 1071.2 & 0.000 \\
\hline 1 & $\square$ & 1 & 1 & 18 & 0.362 & 0.011 & 1091.4 & 0.000 \\
\hline 1 & $\square$ & 1 & 1 & 19 & 0.331 & -0.006 & 1108.5 & 0.000 \\
\hline 1 & $\square$ & 1 & 1 & 20 & 0.306 & 0.017 & 1123.3 & 0.000 \\
\hline 1 & $\square$ & 1 & ים & 21 & 0.287 & 0.098 & 1136.4 & 0.000 \\
\hline 1 & $\square$ & 1 & 1 & 22 & 0.269 & 0.036 & 1148.1 & 0.000 \\
\hline 1 & $\square$ & I & 1 & 23 & 0.276 & 0.023 & 1160.5 & 0.000 \\
\hline 1 & $\square$ & 1 & 1 & 24 & 0.288 & -0.029 & 1174.1 & 0.000 \\
\hline 1 & $\square$ & 마 & 1 & 25 & 0.242 & -0.180 & 1183.8 & 0.000 \\
\hline 1 & 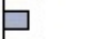 & 1 & 1 & 26 & 0.201 & -0.009 & 1190.6 & 0.000 \\
\hline 1 & 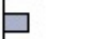 & 1 & ו & 27 & 0.192 & 0.069 & 1196.8 & 0.000 \\
\hline 1 & $\sqsupseteq$ & 1 & י & 28 & 0.179 & 0.070 & 1202.3 & 0.000 \\
\hline 1 & 口 & 1 & 1 & 29 & 0.165 & -0.034 & 1206.9 & 0.000 \\
\hline 1 & り & 1 & ים & 30 & 0.159 & 0.109 & 1211.3 & 0.000 \\
\hline 1 & 口 & 1 & 1 & 31 & 0.153 & 0.036 & 1215.4 & 0.000 \\
\hline 1 & 口 & 1 & 1 & 32 & 0.139 & -0.090 & 1218.8 & 0.000 \\
\hline 1 & 口 & 1 & 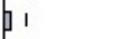 & 33 & 0.138 & 0.054 & 1222.2 & 0.000 \\
\hline 1 & יا" & 10 & 1 & 34 & 0.129 & -0.060 & 1225.3 & 0.000 \\
\hline 1 & 口 & 1 & 1 & 35 & 0.143 & 0.005 & 1229.0 & 0.000 \\
\hline 1 & 口 & 10 & 1 & 36 & 0.159 & -0.034 & 1233.7 & 0.000 \\
\hline
\end{tabular}

Source: Authors, based on Statistical Office of the Republic of Serbia data and EViews 7 data

The decreasing trend of autocorrelation and partial correlation after the first lag shows non-stationarity of time series. Finally,unit root tests (Augmented Dickey-Fuller Unit Root Test and Phillips-Perron Unit Root Test) are the third confirmation of accuracy of the conclusion concerning the basic data nonstationarity.Null hypothesis forecasts the existence of unit root, i.e. nonstationarity of the time series. Gained value of the Augmented Dickey-Fuller test statistic is 1,476235 , what is less than a critical value of this test for the error level of $5 \%$. All that indicates the acceptance of the null hypothesis and the existence of non-stationarity. 
250 Mladenović, Lepojević,Janković-Milić/Economic themes, 54(2): 233-260

Table 4 Augmented Dickey-Fuller and Phillips-Perron Unit Root Test for Export

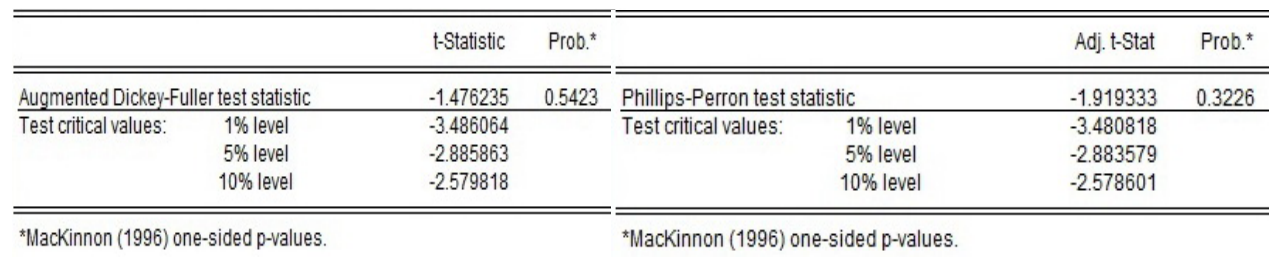

Source: Authors, based on Statistical Office of the Republic of Serbia data and EViews 7 data

With the aim of achieving stationarity, we firstly conducted a transformation of time series through the logarithm, and afterwords a process of differentiating of the first and second order. A stationarity of the analysed series is confirmed by correlogram and mentioned tests, that followed.

\section{Graph 9 Correlogram of logexport for the second derivative}

\begin{tabular}{|c|c|c|c|c|c|c|}
\hline Autocorrelation & Partial Correlation & & $A C$ & PAC & Q-Stat & Prob \\
\hline$\square 1$ & $\square$ । & & -0.441 & -0.441 & 25.897 & 0.000 \\
\hline 日 1 & $\square 1$ & & -0.233 & -0.531 & 33.164 & 0.000 \\
\hline 1曰 & 日1 & & 0.278 & -0.196 & 43.619 & 0.000 \\
\hline$\sqrt{1}$ & , & & -0.155 & -0.321 & 46.873 & 0.000 \\
\hline וביו & 回， & & 0.069 & -0.126 & 47.532 & 0.000 \\
\hline 11 & , & & -0.013 & -0.196 & 47.556 & 0.000 \\
\hline $1 \mathrm{~h}$ & 11 & & 0.031 & 0.001 & 47.692 & 0.000 \\
\hline 10 & 의 1 & & -0.106 & -0.215 & 49.274 & 0.000 \\
\hline ص日 & ص日 & 9 & 0.223 & 0.240 & 56.299 & 0.000 \\
\hline 1 & 151 & 10 & -0.200 & -0.080 & 62.022 & 0.000 \\
\hline : & I & 11 & -0.258 & -0.481 & 71.656 & 0.000 \\
\hline 1 & 11 & 12 & 0.595 & -0.017 & 123.06 & 0.000 \\
\hline & 呐 & 13 & -0.180 & 0.220 & 127.82 & 0.000 \\
\hline 미 1 & 11 & 14 & -0.282 & 0.027 & 139.59 & 0.000 \\
\hline 1曰 & ובי & 15 & 0.254 & 0.077 & 149.24 & 0.000 \\
\hline $10 \sqrt{1}$ & 15 & 16 & -0.082 & 0.061 & 150.26 & 0.000 \\
\hline 111 & 111 & 17 & -0.022 & 0.037 & 150.33 & 0.000 \\
\hline $1 \mathrm{~h}$ & 101 & 18 & 0.038 & -0.083 & 150.56 & 0.000 \\
\hline 1 & 1 & 19 & 0.028 & 0.070 & 150.68 & 0.000 \\
\hline id 1 & ic 1 & 20 & -0.111 & -0.066 & 152.59 & 0.000 \\
\hline ש & ון ו & 21 & 0.210 & 0.101 & 159.56 & 0.000 \\
\hline$\sqrt{1}$ & - 1 & 22 & -0.231 & -0.213 & 168.04 & 0.000 \\
\hline 回 1 & 回 1 & 23 & -0.138 & -0.126 & 171.10 & 0.000 \\
\hline $1=$ & $1] 1$ & 24 & 0.486 & 0.015 & 209.35 & 0.000 \\
\hline 1 & ibi & 25 & $\begin{array}{l}-0.193 \\
\end{array}$ & 0.069 & 215.42 & 0.000 \\
\hline 日 & ו & 26 & -0.179 & 0.064 & 220.73 & 0.000 \\
\hline ים & 11 & 27 & 0.114 & -0.047 & 222.87 & 0.000 \\
\hline 151 & 1 h & 28 & 0.054 & 0.036 & 223.37 & 0.000 \\
\hline 101 & 111 & 29 & -0.081 & 0.040 & 224.49 & 0.000 \\
\hline 11 & id & 30 & -0.004 & -0.100 & 224.49 & 0.000 \\
\hline ים & וקו & 31 & 0.119 & 0.080 & 226.93 & 0.000 \\
\hline$[1$ & 181 & 32 & -0.168 & -0.046 & 231.85 & 0.000 \\
\hline כ1 & 101 & 33 & 0.168 & -0.081 & 236.87 & 0.000 \\
\hline 1 & 111 & 34 & -0.105 & 0.035 & 238.85 & 0.000 \\
\hline I & 10 & 35 & -0.220 & -0.079 & 247.62 & 0.000 \\
\hline $1=$ & 111 & 36 & 0.473 & 0.023 & 288.38 & 0.000 \\
\hline
\end{tabular}

Source: Authors, based on Statistical Office of the Republic of Serbia data and EViews 7 data

As it is shown in the previous graph, the autocorrelation and partial correlation of logexport do not have a decreasing trend, as it was the case with 
the indicator export, what is the first sign of the stationarity of gained time series after a process of differentiating and logarithmic process.

After the process of transformation of the original series, the result of the Augmented Dickey-Fuller test for the second derivative indicates the value of 5.757437, what is greater than this test value for 5\% level (2.886290). The same is with the t-statistics for the Phillips-Perron test, which amounts 71.69636, what is also greater than the test value for the $5 \%$ level. In that way we have adopted an alternative hypothesis on the absence of unit roots, i.e. time series stationarity.

Table 5 Augmented Dickey-Fuller and Phillips-Perron Unit Root Test - Logexport, The second dirivative

\begin{tabular}{|c|c|c|c|c|c|c|}
\hline & & $\mathrm{t}$-Statistic & Prob. ${ }^{*}$ & & Adj. t-Stat & Prob. ${ }^{*}$ \\
\hline \multicolumn{2}{|c|}{ Augmented Dickey-Fuller test statistic } & -5.757437 & 0.0000 & Phillips-Perron test statistic & -71.69636 & 0.0001 \\
\hline \multirow[t]{3}{*}{ Test critical values: } & $1 \%$ level & -3.487046 & & Test critical values: $\quad 1 \%$ level & -3.481623 & \\
\hline & $5 \%$ level & -2.886290 & & $5 \%$ level & -2.883930 & \\
\hline & $10 \%$ level & -2.580046 & & $10 \%$ level & -2.578788 & \\
\hline
\end{tabular}

Source: Authors, based on Statistical Office of the Republic of Serbia data and EViews 7data

The estimation stage is the second and the most extensive stage of the BoxJenkins methodology, where is supposed to be created model that will be reduced on one model after the diagnostics. This reduced model will be used for the Republic of Serbiafuture export values forecast. The existing empirical researches indicate various models which are used depending on a time series type. In our case, aiming to get the most effective ARIMA model, special attention will be dedicated to the choice of autoregressive variables (the lags of the dependent variable) and moving average (the lags of residual values). During the research there have been 25 checked models with different combinations of AR and MA variables. According to the Akaike and Schwarz criteria, model $\mathrm{AR}(1) \operatorname{SAR}(12) \mathrm{MA}(1) \operatorname{SMA}(12)$, i.e. $(1,2,1) \times(12,2,12)_{12}$ is highlighted as the most acceptable.

Within the diagnostic checking stage, it is estimated the validity of the chosen model, based on its compatibility with the real data and quality of its predictive power. According to the histogram and correlograms (the correlogram of residuals and the correlogram of residuals squares) chosen model has the normal distribution of residuals, while its autocorrelation and partial correlation show random movement of residuals. 


\section{Graph 10 Histogram of ARIMA residuals}

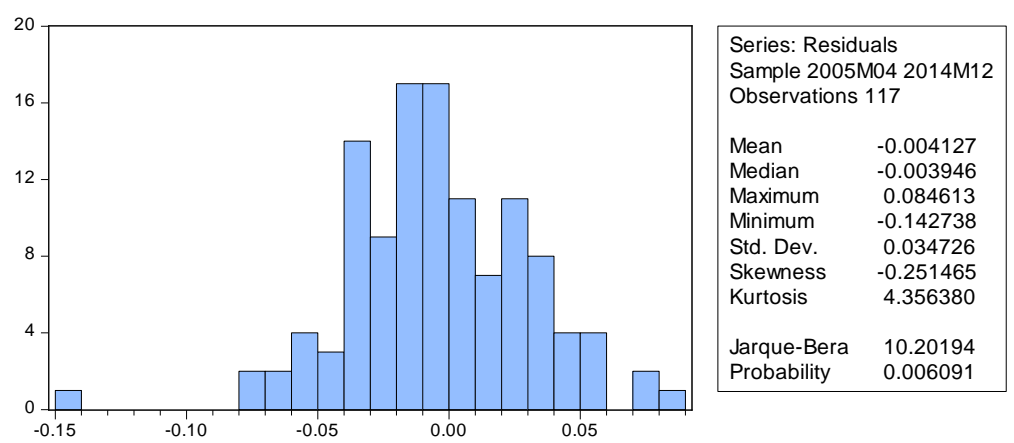

Source: Authors, based on Statistical Office of the Republic of Serbia data and EViews 7data

\section{Graph 11 Correlogram of residuals and correlogram of residuals squares}

\begin{tabular}{|c|c|c|c|c|c|c|c|c|}
\hline \multicolumn{2}{|c|}{ Autocorrelation } & \multicolumn{2}{|c|}{ Partial Correlation } & & $A C$ & PAC & Q-Stat & Prob \\
\hline 1 & 1 & 1 & 1 & & -0.001 & -0.001 & 0.0003 & \\
\hline 1 & b & 1 & 1 & 2 & 0.049 & 0.049 & 0.2857 & \\
\hline 1 & ין & 1 & ا & & 0.133 & 0.133 & 2.4334 & \\
\hline 10 & & 10 & 1 & & -0.069 & -0.071 & 3.0183 & \\
\hline 1 & & 1. & اط & & 0.141 & 0.131 & 5.4961 & 0.019 \\
\hline 10 & & 10 & 1 & & -0.079 & -0.095 & 6.2803 & 0.043 \\
\hline 10 & 1 & 10 & 1 & & -0.079 & -0.073 & 7.0791 & 0.069 \\
\hline 10 & 1 & I & 1 & & -0.066 & -0.103 & 7.6308 & 0.106 \\
\hline 14 & 1 & 10 & 1 & & -0.081 & -0.034 & 8.4678 & 0.132 \\
\hline 15 & 1 & 14 & 1 & 10 & -0.067 & -0.075 & 9.0455 & 0.171 \\
\hline 미 & 1 & 10 & 1 & 11 & -0.132 & -0.098 & 11.343 & 0.124 \\
\hline 10 & 1 & 11 & 1 & 12 & -0.038 & -0.016 & 11.530 & 0.173 \\
\hline 1 & ום & 1 & إل & 13 & 0.083 & 0.121 & 12.459 & 0.189 \\
\hline 14 & 1 & 14 & 1 & 14 & -0.089 & -0.075 & 13.528 & 0.196 \\
\hline 1 & 1 & 1 & 1 & 15 & 0.016 & 0.004 & 13.563 & 0.258 \\
\hline 1 & 1 & 10 & 1 & 16 & -0.021 & -0.042 & 13.624 & 0.325 \\
\hline 1 & b & 1 & 1 & 17 & 0.065 & 0.078 & 14.208 & 0.359 \\
\hline 1 & 1 & 10 & 1 & 18 & 0.006 & -0.080 & 14.213 & 0.434 \\
\hline 叫 & 1 & 1 & 1 & 19 & -0.133 & -0.132 & 16.712 & 0.336 \\
\hline 1 & bi & 1 & 1 & 20 & 0.043 & 0.003 & 16.980 & 0.387 \\
\hline 14 & 1 & 14 & 1 & 21 & -0.060 & -0.042 & 17.501 & 0.421 \\
\hline 回 & 1 & 드 & 1 & 22 & -0.150 & -0.193 & 20.817 & 0.289 \\
\hline 1 & b & 1. & ו & 23 & 0.062 & 0.070 & 21.394 & 0.315 \\
\hline 叫 & 1 & 10 & 1 & 24 & -0.103 & -0.035 & 22.973 & 0.290 \\
\hline 10 & 1 & 10 & 1 & 25 & -0.043 & -0.050 & 23.247 & 0.331 \\
\hline 1 & bi & 1 & 1 & 26 & 0.062 & 0.007 & 23.830 & 0.356 \\
\hline 叫 & 1 & 10 & 1 & 27 & -0.123 & -0.061 & 26.160 & 0.293 \\
\hline 1 & 1 & 14 & 1 & 28 & -0.012 & -0.079 & 26.184 & 0.344 \\
\hline 1 & 1 & 11 & 1 & 29 & 0.017 & -0.024 & 26.230 & 0.395 \\
\hline 1 & 1 & 10 & 1 & 30 & -0.006 & -0.061 & 26.234 & 0.450 \\
\hline 1 & 1 & 10 & 1 & 31 & -0.016 & -0.054 & 26.277 & 0.503 \\
\hline 14 & 1 & 10 & 1 & 32 & -0.027 & -0.055 & 26.395 & 0.551 \\
\hline 1 & 11 & 10 & 1 & 33 & 0.029 & -0.037 & 26.538 & 0.597 \\
\hline 1 & b & 1 & 11 & 34 & 0.045 & 0.032 & 26.878 & 0.630 \\
\hline 1 & 1 & 11 & 1 & 35 & 0.004 & -0.015 & 26.881 & 0.678 \\
\hline 1 & & 1 & 1 & & 0.053 & 0.004 & 27.368 & 0.700 \\
\hline
\end{tabular}

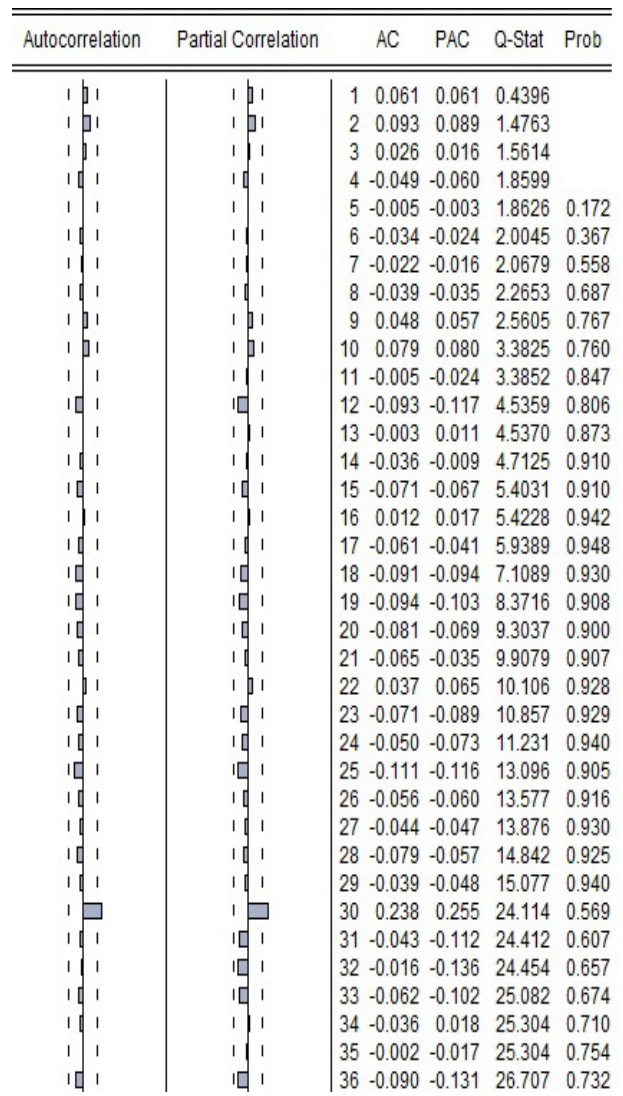

Source: Authors, based on Statistical Office of the Republic of Serbia data and EViews 7 data 
The key parameters gained within the diagnostic checking stage also demonstrate the validity of the chosen model. These parameters are the coefficient of determination $\left(\mathrm{R}^{2}\right)$, the values of Durbin-Watson statistics and the significance of $F$ statistics. In the following picture, we can see that chosen model's coefficient of determination is $83.3 \%$, what implies that the model explains $83.3 \%$ of the variance of the dependent variable. The Durbin-Watson $\mathrm{d}$ statistics is used for the testing of the first order autocorrelation existence. If $\mathrm{d} \approx$ 2 model has the uncorrelated residuals, while $\mathrm{d} \approx 0$ means a sufficiently strong autocorrelation. Finally, an autocorrelation is negative when $d>2$. In our case the Durbin-Watson d statistics amounts 1.97, what implies the existence of uncorrelated residuals. Concerning the F statistics significance of 0,00 , we can conclude that chosen model is statistically significant for the error level of $1 \%$.

\section{Graph 12 The key indicators of the gained model}

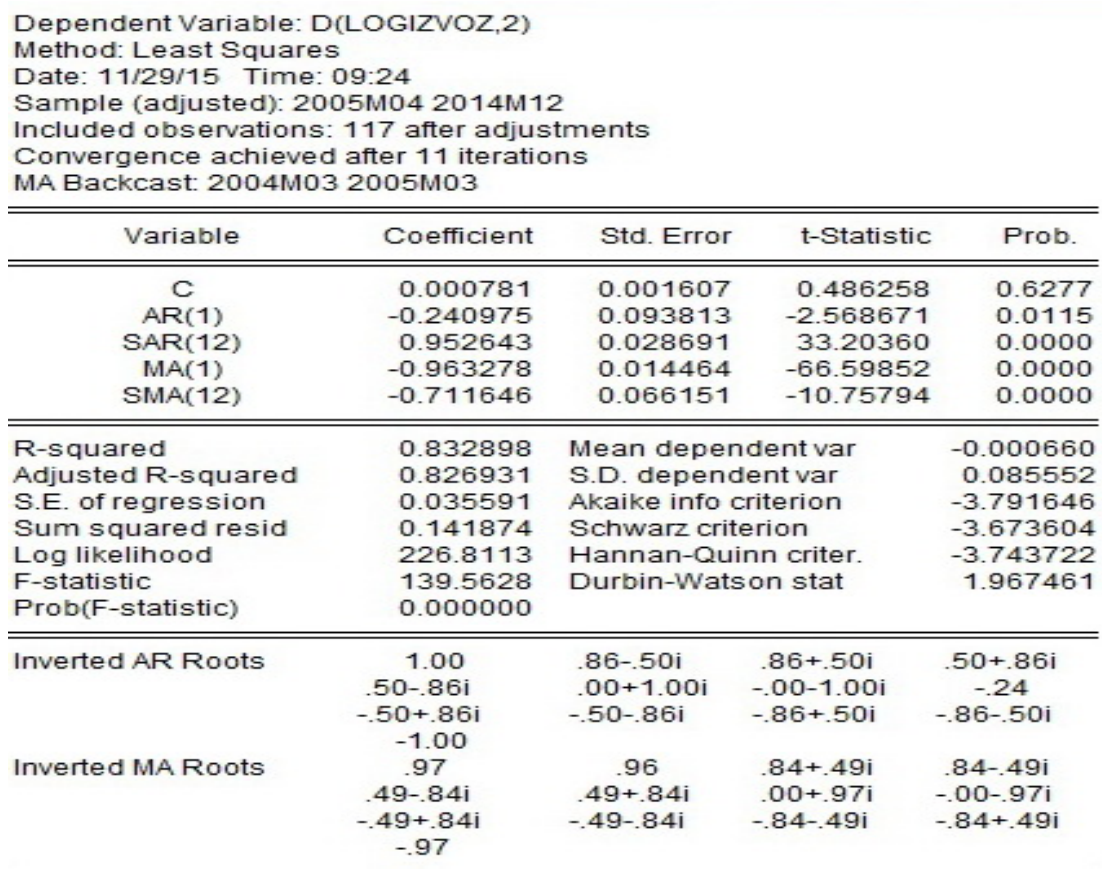

Source: Authors, based on Statistical Office of the Republic of Serbia data and EViews 7 data

The test of heteroscedasticity (White test) is one more indicator of the model validity. Its value is smaller than the critical value for the Hi square $0.05 ; 20$, what is 31.410 . Thus, the assumption about the model variance homoscedasticity is accepted. In that way it is shown that the model cannot be further widened and used with the aim of a log run forecasting (GARCH). 


\section{Graph 13 White test - test of heteroscedasticity}

Heteroskedasticity Test: White

\begin{tabular}{llll}
\hline \hline F-statistic & 0.662053 & Prob. $F(20,96)$ & 0.8533 \\
Obs*R-squared & 14.18152 & Prob. Chi-Square(20) & 0.8212 \\
Scaled explained SS & 22.31853 & Prob. Chi-Square(20) & 0.3235 \\
\hline \hline
\end{tabular}

Source: Authors, based on Statistical Office of the Republic of Serbia data and EViews 7 data

In order to forecast the further values, the original number of observations is modified for the length of the forecast horizon. Concerning the tendency of the export forecast for the period January-December 2015, the following graph was gained. It incorporates three scenarios of the future export trends, where optimistic and pessimistic scenarios are determined as \pm two standard errors of the real export trend.

\section{Graph 14 Optimistic, pessimistic and realistic scenario of export's} movement, 2015

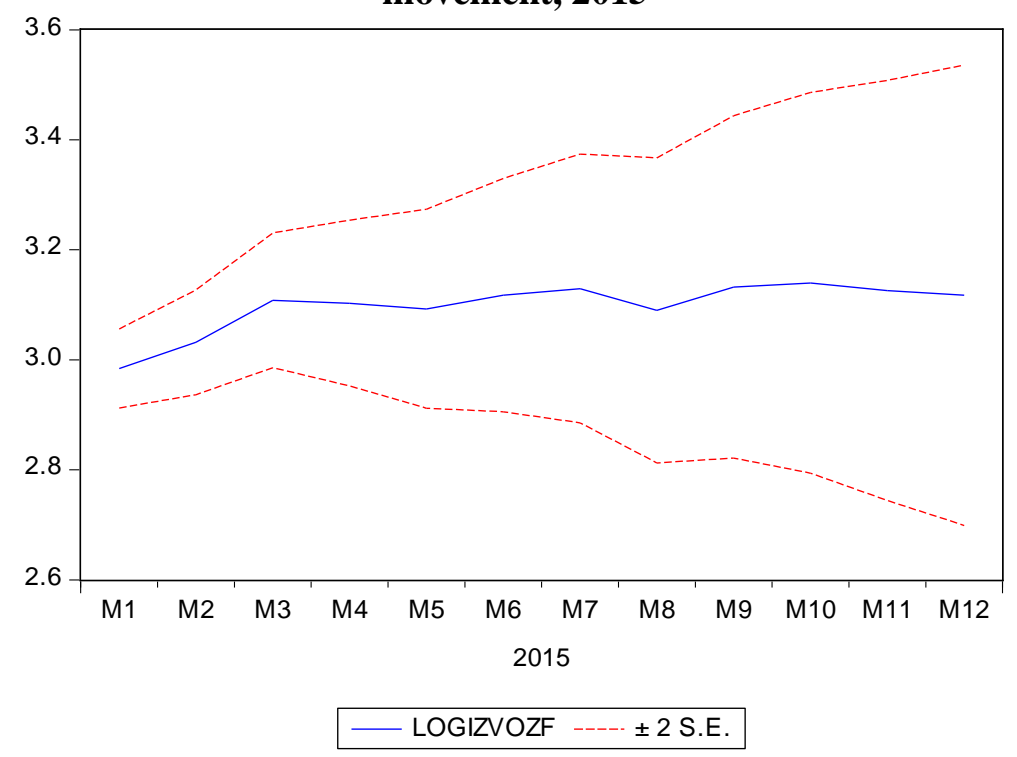

Source: Authors, based on Statistical Office of the Republic of Serbia data and EViews 7 data

The optimistic scenario shows that export values will amount from 3 to 3.6 units in $y$ axis during 2015. That is equivalent to the range from 1.000 to 3,981.07 million dollars. According to thepessimistic scenario, export will have a decreasing tendency in the same period, from 2.85 to 2.70 units in $y$ axis, i.e. from 630.96 to 398.11 million dollars. Eventually, the realistic scenario 
forecasts the movement of export values about the third unit in $y$ axis, i.e. about billion dollars, with the slow increasing tendency.

Final graph presents export trends in the period January 2004-December 2015. The same graph includes both, the real and forecasted values of the observed variable.

Graph 15 Real (2004-2014) and forecasted(2015) export values, Republic of Serbia, million \$

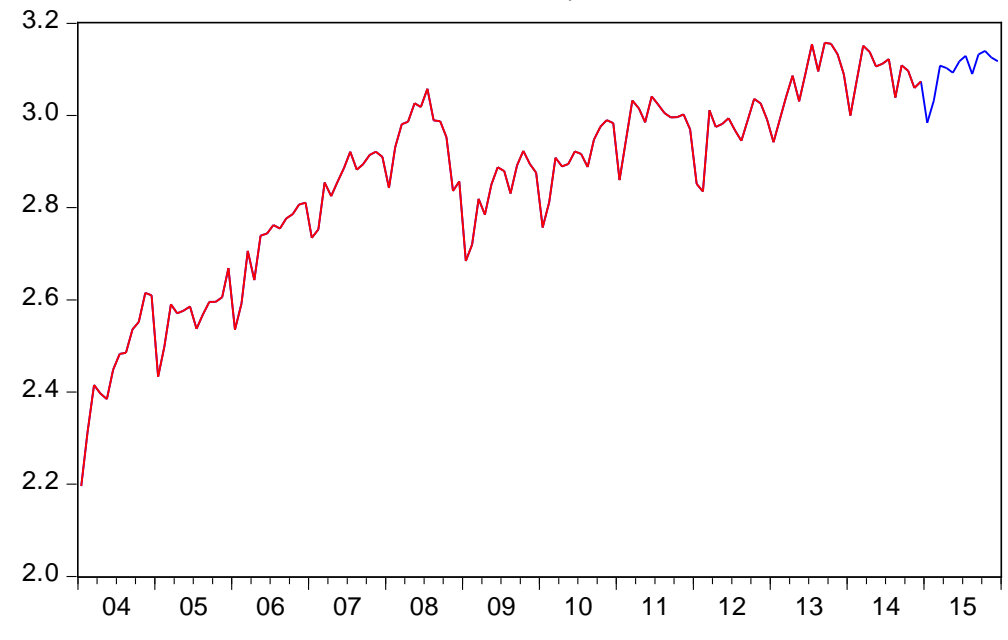

$$
\text { - LOGIZVOZF - LOGIZVOZ }
$$

Source: Authors, based on Statistical Office of the Republic of Serbia data and EViews 7 data

In the part of the graph that presents forecasted values, we can see that export will primarily decline, while the increasing tendency will begin from March 2015. This tendency will be present until the end of analysed year. Finally, the analysis resulted in the following forecasted values of export trends during 2015.

There is noticed the lowest forecasted export value in January, 963.22 million dollars, while the largest forecasted value can be expected in October, 1,377.53 million dollars. 
256 Mladenović, Lepojević,Janković-Milić/Economic themes, 54(2): 233-260

Table 6 Forecasted values of export trends during 2015 in million dollars

\begin{tabular}{|cc|}
\hline Month & Export value \\
\hline January & $\mathbf{9 6 3 . 2 2 0 6}$ \\
\hline February & 1074.639 \\
\hline March & 1282.044 \\
\hline April & 1265.863 \\
\hline May & 1236.737 \\
\hline Jun & 1309.642 \\
\hline July & 1345.767 \\
\hline Avgust & 1228.662 \\
\hline September & 1354.747 \\
\hline October & $\mathbf{1 3 7 7 . 5 3 1}$ \\
\hline November & 1334.493 \\
\hline December & 1308.219 \\
\hline
\end{tabular}

Source: Authors, based on Statistical Office of the Republic of Serbia data and EViews 7 data

Graph 16: Forecasted export values during 2015, million dollars

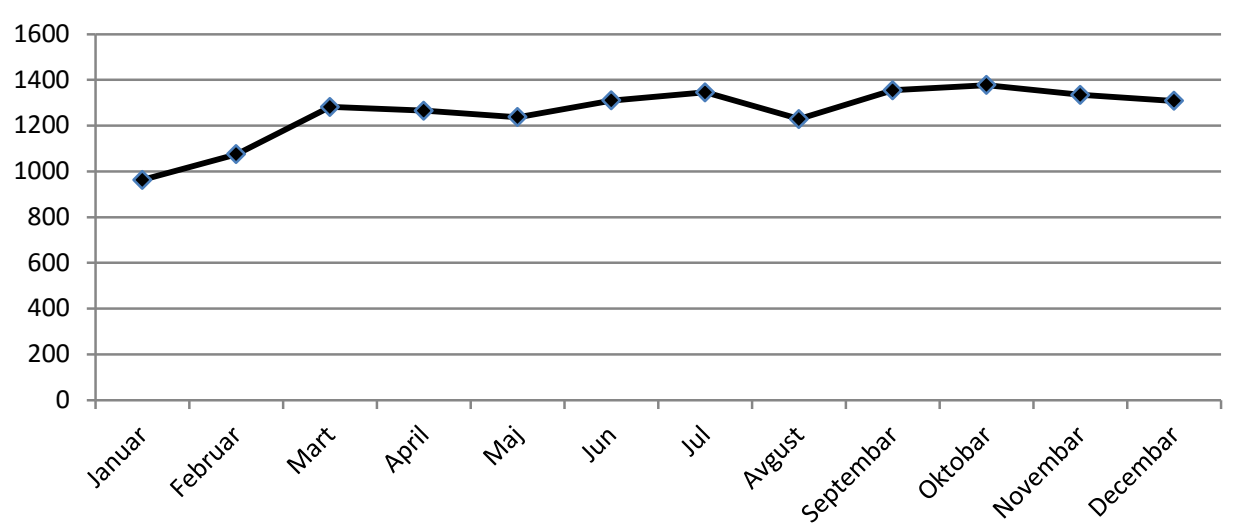

Source: Authors, based on Statistical Office of the Republic of Serbia data and EViews 7 data

Clearer view of the forecasted export values is shown in the graph above. According to it as well as the Table 6, it can be concluded that an increasing trend is present during the summer, while a decline in the export values can be expected after October. 


\section{Conclusion}

The paper presented the analysis of export trends of the Republic of Serbia with the explanation of variations in the conduct of export from January 2004 to December 2014. Furthermore, the paper provided an insight into the export trend forecast for the 12-month period, and thus proved the possibilities of practical usage of time series analysis methods in the forecasting macroeconomic variables, such as export.

The analysis of domestic export during the 11 month period recognises a chronic foreign trade deficit as the key characteristic of the foreign trade position of the Republic of Serbia. As one of the crucial problems is identified the import of numerous products which are produced in the country in a sufficient extent, as well as a predominant export of primary and unprocessed products. Despite this negative side, as the positive feature of the foreign trade of the Republic of Serbia is noticed as the increase in import contents of export.The same indicator increased from $32.7 \%$ in 2004 to $72 \%$ in the last analysed year, 2014. As the most important foreign trade partner is identified Italy, while trade with Bosnia and Hercegovina provides the largest surplus. The fact about the foreign trade deficit in trade with the Russian Federation, in spite of the existing free trade agreement, sets as an imperative to the usage of taxfree export advantages, as well as an increase in the quantity of products that will be exported into that country. As for a contribution of some economic activities to the foreign trade balance, predominant positive effect of agriculture, forestry and fishing should be emphasized. Thus, these activities should have primary importance within the planning of encouragements for production in the following period. Finally, a low labor force costs are one of the key factors of the encouragement of export through the production by lower prices.

The paper provided application of two different approaches in the process of modeling and prognosis of economic time series. The observed methods of time series analysis have been used as a tool for research of existing export trends, but for forecasting export values in the Republic of Serbia for the 12-month period, too.

Gained results confirm the theoretical features of used models. Two models, additive and multiplicative, were developed within the Holt-Winters smoothing, in order to check the quality of the gained forecasts and chose the model that shows greater reliability level. Both models used following parameters: 0.7 for alfa $(\alpha), 0.5$ for beta $(\beta)$ i 0.2 for gama $(\gamma)$. As forecasted values were closer to the empirical data in the case of multiplicative model, as well as smoothing error was smaller for the root mean square error (RMSE) and the residual sum of squares (RSS) in the multiplicative model, it was chosen as more qualitative for forecast. 
In the end, the paper also included the application of ARIMA (Autoregressive Integrated Moving Average) method, whose long run forecasts are considered as more qualitative in a comparison to the other gained by the Holt-Winters smoothing. For the year 2015, ARIMA method identified the increase of export values during the summer and their decrease after October. According to that forecast, the lowest forecasted value is expected in January, while the greater one is forecasted for October. That forecast is mostly compatible with one gained by the Holt-Winters smoothing, what implies high quality of used methods in the analysis of macroeconomic indicators such as export.

\section{Literature}

Acin, Đ., Todorović, M. \& Acin-Sigulinski, S. (2006). Međunarodni ekonomski odnosi. Novi Sad:Pigmalion.

Baldigara, T. \&Mamula, M. (2015). Modelling International Tourism Demand Using Seasonal ARIMA Models.Tourism and Hospitality Management, 21(1), 19-31.

Brockwell, D. R. (2002). Introduction to Time Series and Forecasting. New York:Springer-Verlag.

Dobre, I. \& Alexandru, A.AM. (2008). Modelling Unemployment Rate Using BoxJenkins Procedure.Journal of Applied Quantitative Methods, 3(2), 156-166.

Etuk, E.H. (2012). Predicting Inflation Rates of Nigeria Using a Seasonal Box-Jenkins Model.Journal of Statistical and Econometric Methods, 1(3), 27-37.

Hultman, Ch. (1967). Exports and Economic Growth: A Survey.Land Economics, 43(2), 148-157.

Hussain, M. \& Saaed, A. (2015). The causality relation between export, import and economic growth: UAE Case.International Journal Of Management Cases, 17(3), 68-87.

Ibrahim, I. \& MacPhee, C. (2003). Export externalities and economic growth.Journal of International Trade and Economic Development, 12(3), 257-283.

Republički Zavod za statistiku (webrzs.stat.gov.rs), pristupljeno 05.12.2015.

Jankovic-Milic, V., Lepojevic, V. \& Djordjevic, V. (2011). Adaptive Filtering Method in Business Forecasting.U: Spasić, D. (Ed.), Problems of Competitiveness of Contemporary Economies (str. 485-492). Ниш:Економски факултет.

Kirchgassner, G. \& Wolters, J. (2007). Introduction to Modern Time Series Analysis. Berlin: Springer.

Koehler, A., Snyder, R., Ord, J.K. (2001). Forecasting models and prediction intervals for the multiplicative Holt-Winters method. International Journal of Forecasting, 17, 269-286.

Kovačić, Z. (1995). Analiza vremenskih serija. Beograd:Ekonomski fakultet.

Kovačić, Z. (1998). Analiza vremenskih serija. Beograd:Ekonomski fakultet.

Kravis, I. (1970). Trade as a Handmaiden of Growth: Similarities Between the Nineteenth and Twentieth Centuries. Economic Journal, 80, 850-872.

Lawton, R. (1998). How should additive Holt-Winters estimates be corrected? International Journal of Forecasting, 14, 393-403. 
Lepojevic, V. \& Andjelkovic-Pesic, M. (2011). Forecasting Electricity Consumption by Using Holt-Winters and Seasonal Regression Models.FactaUniversitatis, Series: Economics and Organization, 8(4), 421-431.

Lepojević, V. \& Janković-Milić, V. (2011).Prognoziranje mesečne inflacije u Srbiji primenom eksponencijalnog i Holt-Wintersovog izravnanja. U: Krstić, B. (Ed.), Unapređenje konkurentske prednosti javnog $i$ privatnog sektora umrežavanjem kompetencija u procesu evropskih integracija Srbije (str. 435-442). Niš: Ekonomski fakultet.

Marković, I. \& Marković, M. (2014). Uticaj transmisionog mehanizma deviznog kursa na konkurentnost izvoza Srbije. Економске теме, 2, 205-221.

McClave \& James, T (1988).Statistics for Business and Economics. San Francisco: Dellen Publishing Company.

Milenković, N. (2012). Devizni kurs kao instrument ekonomske politike - iskustva zemalja Istočne Azije.Ekonomski horizonti, 14(3), 139-149.

Mladenović, Z. \& Nojković, A. (2008). Analiza vremenskih serija: Primeri iz srpske privrede.Beograd: Ekonomski fakultet Beograd.

Moon, B. (1998). Exports, Outward-Oriented Development, and Economic Growth. Political Research Quarterly, 51(1), 7-36.

Mottaleb, K.A. \& Kalirajan, K. (2014). Determinants of Labor-intensive Exports by the Developing Countries: A Cross Country Analysis. The Singapore Economic Review, 59(5), 1450043-1 - 1450043-22

Rati, R. (1985). Exports and Economic Growth: Some Additional Evidence.Economic Development and Cultural Change, 33(2), 415-425.

Taylor, J. W. (2003). Short-Term Electricity Demand Forecasting Using Double Seasonal Exponential Smoothing. Journal of Operational Research Society, 54, 799-805.

Todorović, M. \& Marković, I. (2013). Međunarodna ekonomija. Niš: Ekonomski fakultet.

Valakevicius, E. \& Brazenas, M. (2015). Application of the Seasonal Holt-Winters Model to Study Exchange Rate Volatility. Inzinerine Ekonomika-Engineering Economics, 26(4), 384-390.

\section{MODELIRANJE I PROGNOZIRANJE IZVOZA REPUBLIKE SRBIJE PRIMENOM SEZONSKOG HOLT-WINTERSOVOG I ARIMA METODA}

Apstrakt: Niska cena radne snage kao jedan od ključnih izvora podsticanja izvoza, konkurentska prednost domaće poljoprivredne proizvodnje i bilateralni sporazumi sa partnerskim zemljama favorizuju izvoz kao potencijalno značajan faktor podsticanja privrednog razvoja Republike Srbije. Imajući u vidu ovu činjenicu, sa jedne strane, i platnobilansne probleme sa kojima se Srbija suočava tokom niza godina, sa druge strane, predmet ovog rada je analiza kretanja izvoza Republike Srbije i utvrđivanje zakonitosti u ponašanju ove makroekonomske varijable tokom perioda od 2004. do 2014. godine. Cilj rada predstavlja prognoziranje kretanja izvoza u periodu od januara do decembra 2015. godine. U analizi su korišćeni Holt- 
Winters i ARIMA metode za analizu vremenskih serija. Rad je pružio uvid u prognozu kretanja izvoza za period od 12 meseci i time ukazao na mogućnost praktične upotrebe metoda analize vremenskih serija u prognozi makroekonomskih varijabli poput izvoza. Korišćene metode su identifikovale trend kretanja tokom 2015. godine pri kome dolazi do rasta vrednosti izvoza tokom letnjih meseci uz smanjenja istih nakon oktobra. Rad je utvrdio postojanja visokog stepena podudarnosti dobijenih prognoza putem dva korišćena metoda, što govori u prilog visokom kvalitetu obrađenih metoda u analizi izvoza.

Ključne reči: Izvoz, ARIMA, Holt-Winters metod, Box-Jenkins metodologija, spoljna trgovina, vremenske serije

\section{Authors' biographies}

Jelena Mladenović is a $\mathrm{PhD}$ student at the Faculty of Economics in Niš. She is a scholar of the Ministry of Education, Science and Technological Development. She worked as a volunteer assistant at the Centre for Economic Research of the Faculty of Economics in Nis. She was also involved in the project "Improving the Competitiveness of Public and Private Sector by networking competences in the process of European integration of Serbia", funded by the abovementioned Ministry. During 2013/2014 and 2014/2015 school year, she worked as a demonstrator at Faculty of Economics in Niš. As a holder of scholarship programme "Serbia-Norway Scholarship Scheme", during the master studies in the summer semester of 2013 she stayed at the Norwegian University of Science and Technology. She is the recipient of a scholarship Constantine (2012/2013.), scholarship programmme Partnership for Education and Community Development (2012), a scholarship fund for young talents (2010-2012).

Vinko Lepojević graduated from the Faculty of Economics in 1990, received his M.Sc. (1995) at the Faculty of Economics in Belgrade and PhD (2008) at the Faculty of Economics in Niš. He is an Associate Professor at the Faculty of Economics in Nis, teaching the subjects Statistics, Statistic Analysis in Marketing, Statistical Quality Control and Quantitative Methods in Economics. He has published nearly a hundred scientific and professional papers in domestic and international journals. His fields of interest include quantitative methods in economics and statistical analysis.

Vesna Janković Milić graduated from the Faculty of Economics in 1996. She received her MSc (2004) at the Faculty of Economics in Belgrade and PhD (2010) at the Faculty of Economics in Nis. She is an Associate Professor at the Faculty of Economics, University of Nis. She is the author of more than hundred scientific and professional papers. Her research interests include an application of quantitative, especially statistical, methods in economic research. She participates in many project financed by Ministry of Science Republic of Serbia. 